\title{
Comparison between the municipal solid waste management of two municipalities from mountain region
}

\begin{abstract}
This paper aims to present a review of household waste management in two small municipalities located at Mountain Region (RS - Brazil). As method, it was used data from waste amounts destined for regular and selective collection, physical characterization and gravimetric composition of the waste generated in three neighbourhoods of different social classes. It was observed that the largest municipality showed better efficiency and higher coverage of selective collection. The per capita index of waste generation was similar among municipalities, despite of differences in population size and in social and economic characteristics. The neighbourhoods with high and middle classes presented better segregation in both collections and municipalities. The presence of biodegradable materials in selective collection (average 14\%) and recyclable materials in regular collection (average 21\%) was observed. The obtained results indicated the necessity to continuously investing on expansion of selective collection and environmental education, in order to improve waste segregation, which contributes with the efficiency level of triage plants, as well as to increase the potential recovery of waste recyclable and the useful life of landfills.
\end{abstract}

Keywords: Recycling; Selective Collection; Regular Collection; Social Classes.

\section{Comparação do gerenciamento municipal de resíduos sólidos entre dois municípios localizados na Serra Gaúcha}

Este estudo apresenta uma análise do gerenciamento de resíduos sólidos domiciliares (RSD) realizado em dois pequenos municípios localizados na região da Serra Gaúcha (RS - Brasil). Em ambos os municípios foram utilizados dados obtidos de pesagem de resíduos destinados às coletas regular e seletiva e dados de caracterização física e composição gravimétrica dos RSD obtidos em três bairros com diferentes classes sociais. Foi observado que o maior município apresentou melhor eficiência e melhor cobertura da coleta seletiva. Os índices de geração per capita de RSD em cada município apresentaram valores similares, mesmo com as diferenças entre as características populacionais, sociais e econômicas. Os bairros de alta e média classe apresentaram melhor segregação em ambas as coletas e municípios. Foi observado ainda, a presença de materiais biodegradáveis na coleta seletiva (média de 14\%) e materiais recicláveis na coleta regular (média de 21\%). Os resultados obtidos demonstram a necessidade de investimentos contínuos na expansão da coleta seletiva e educação ambiental, tendo em vista a melhora da segregação de RSD, fato que contribui para o nível de eficiência de plantas de triagem de resíduos, bem como para o melhor aproveitamento do potencial de reciclabilidade de resíduos recicláveis e aumento da vida útil de aterro sanitários.

Palavras-chave: Reciclagem; Coleta Seletiva; Coleta Regular; Classes Sociais.

\section{Topic: Saneamento e Tratamento de Resíduos}

Reviewed anonymously in the process of blind peer.

\section{Denise Peresin}

Universidade do Vale do Rio dos Sinos

http://lattes.cnpq.br/0445415520926034

deniseperesin@gmail.com

Nícolas Reinaldo Finkler

Universidade de São Paulo

http://lattes.cnpq.br/8925053933200494

nicolas.finkler@gmail.com

Mariana Riegel Grando

Universidade de Caxias do Sul

http://lattes.cnpq.br/4448079635746519

mrgrando@ucs.br

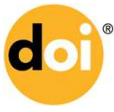

DOI: 10.6008/SPC2179-6858.2016.001.0022
Received: 01/10/2015

Approved: 29/11/2015

\author{
Verônica Casagrande \\ Universidade de Caxias do Sul \\ http://lattes.cnpq.br/7833207034683509 \\ vecasagrande@hotmail.com \\ Elis Marina Tonet Motta \\ Universidade de Caxias do Sul \\ http://lattes.cnpq.br/8969158071670605 \\ elistonet@gmail.com \\ Vania Elisabete Schneider \\ Universidade Federal do Rio Grande do Sul \\ http://lattes.cnpq.br/9940289333509769 \\ veschnei@ucs.br
}

Referencing this:

PERESIN, D.; FINKLER, N. R.; GRANDO, M. R.; CASAGRANDE, V.; MOTTA, E. M. T.; SCHNEIDER, V. E.. Comparação do gerenciamento municipal de resíduos sólidos entre dois municípios localizados na Serra Gaúcha. Revista Ibero-Americana de Ciências Ambientais, v.7, n.1, p.250-260, 2016. DOI: http://doi.org/10.6008/SPC2179$\underline{6858.2016 .001 .0022}$ 


\section{INTRODUCTION}

Increasing population levels, booming economy, rapid urbanization and the rise in living standards has greatly accelerated the municipal solid waste generation rates in developing countries. These factors makes the solid waste management one of the biggest global challenge and, consequently, the necessity of environmental friendly solutions for their disposal (Minghua et al., 2009; Seo et al., 2004; Gallardo, Carlos, Peris, Colomer, 2014).

According to Edjabou et al. (2015), accurate and reliable data on waste composition are crucial both for planning and environmental assessment of waste management as well as for improvement of materials recovery. Therefore, to develop the waste management system and to improve technologies, detailed data about the typology and the characteristics of waste are needed, enabling the development of projects and the identification of related scenario to them. The characterization of solid waste streams and the estimation of their generation rates are considered critical data, required to propose any sustainable management system and to find the most appropriate and viable alternative solutions to Municipal Solid Waste Management (Al-Khatib et al., 2010).

Currently in Brazil, the legal guidelines for solid waste management are defined by the National Policy of Solid Waste - NPSW, Law no 12,305 (Brasil 2010) and, for provision of public services from urban sanitation and solid waste management, through the Basic Sanitation Law, Federal Law no 11,445 (Brasil 2007). It is noteworthy that, among other requirements, the NPSW established the requirement for developing the Integrated Solid Waste Management Plan (ISWMP), by municipalities, as a condition to access the budgetary resources of the Union. According to the National Information System on Sanitation - NISS (SNIS 2012), 20\% of Brazilian municipalities already have selective collection services, while $35 \%$ have not implemented it yet. A portion of $45 \%$ of Brazilian municipalities did not report the situation of waste collection to the NISS in 2011. From the 497 municipalities that composes Rio Grande do Sul state (RS), 355 municipalities reported that have selective collection in their municipality, which makes Rio Grande do Sul the third state with highest system participation. Regarding to the national scenario, the municipalities located at Mountain Region register an appropriate situation related with waste management and disposal of recyclable waste.

In this sense, this paper aims to present a review of household waste management in two small municipalities located at Mountain Region (RS - Brazil) and compare the results with studies carried out in both Brazil and developed countries. This analysis will be performed by the results obtained through the generated waste quantities for the regular and selective collections, as well as through the segregation efficiency analysis by the population of different social classes. The results presented in this paper are considered essential for environmental municipal planning and, in the same way, for further studies related to municipal management of solid household waste (SHW).

\section{MATERIALS AND METHODS}


The study has been conducted in two municipalities at Mountain Region - northeast of Rio Grande do Sul, Brazil - that are approximately $60 \mathrm{~km}$ from each other (Figure 1). The main features of the municipalities are presented in Table 1.

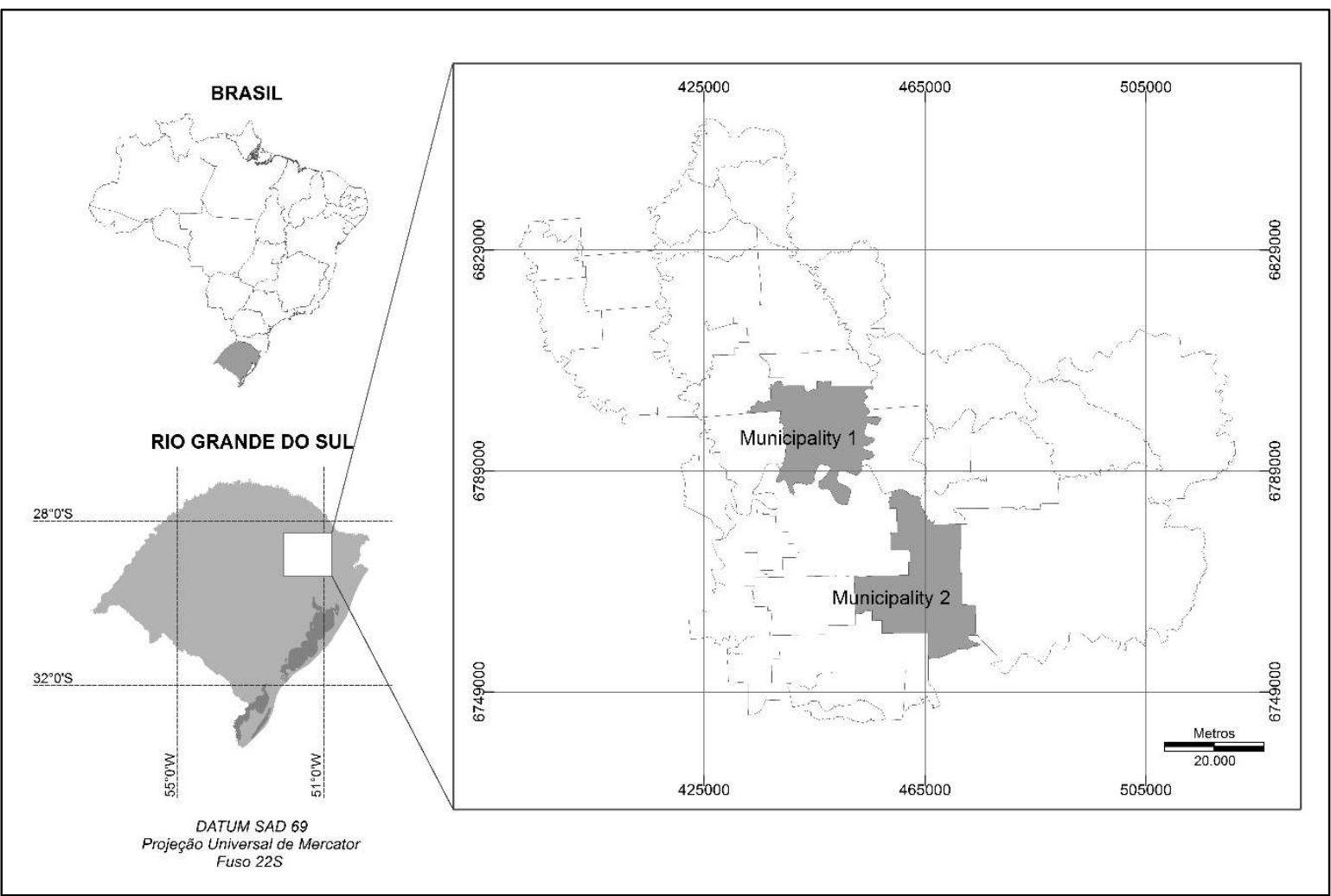

Figure 1: Location map indicating both studying municipalities.

Table 1: Characteristics of municipalities in study.

\begin{tabular}{llrlcl}
\hline & Inhabitants & $\begin{array}{r}\text { Area } \\
\left(\mathbf{k m}^{\mathbf{2}}\right)\end{array}$ & HDI* & $\begin{array}{r}\text { Per capita income } \\
\text { (inhab.year) }\end{array}$ & \multicolumn{1}{c}{ Main economic activities } \\
\hline Municipality 1 & 22,810 & 289.342 & 0.773 & $34,216.58$ & Agricultural production \\
Municipality 2 & 63,635 & 360.390 & 0.777 & $27,555.34$ & $\begin{array}{l}\text { Agricultural production, industry and } \\
\text { trade }\end{array}$ \\
\hline
\end{tabular}

Source: IBGE (2015). * Human Development Index.

Both municipalities have regular and selective collection, and third party companies carry out the services of collection, transportation and final disposal of household solid waste.

In Municipality 1, the waste from regular collection are forwarded to a Transhipment Center, which is located in the same city. After that, the waste is sent to a landfill located in another city, which is distant approximately $240 \mathrm{~km}$ from departure city. In Municipality 2, the waste is disposed in a municipal landfill, which is managed by outsourced company. Regarding to the waste from the selective collection, in both municipalities these are forwarded for triage plants where they are sorted and marketed.

The methodology used for waste characterization in both municipalities followed the proposal of Schneider and Lima (1994), that suggested conducting samples in neighbourhoods with different social classes (Class A - high, B - middle and C - low) for residues of both collections (regular and selective). The samples were collected on predefined dates and routes in the selected neighbourhoods. In the municipality 1 there were performed two characterizations - in July and September of 2011 -, and in the Municipality 2 there were conducted three characterizations - in November 2013, April and June of 2014. 
The initial sample for regular collection was composed by the total waste in the truck, discharged at predefined location. Smaller portions of this sample were taken from 5 different points of the waste mass (top and corners), and these were divided into four subsamples with approximately 200 litters (L). From these subsamples, it was selected the two of them that showed the best waste homogeneity, and were conditioned in two containers of $200 \mathrm{~L}$, so that the voids were avoided. The remaining portions were discarded (Figure 2).

After the final sample composition, the waste was segregated by type of material for later weighing and spreadsheet record. Table 2 shows the spreadsheet model used for selective waste data logging. For the regular collection it was used the same form, however, with only two columns for the results (samples $A$ and B), since the method for the regular collection predicts the use of only two samples of $200 \mathrm{~L}$.

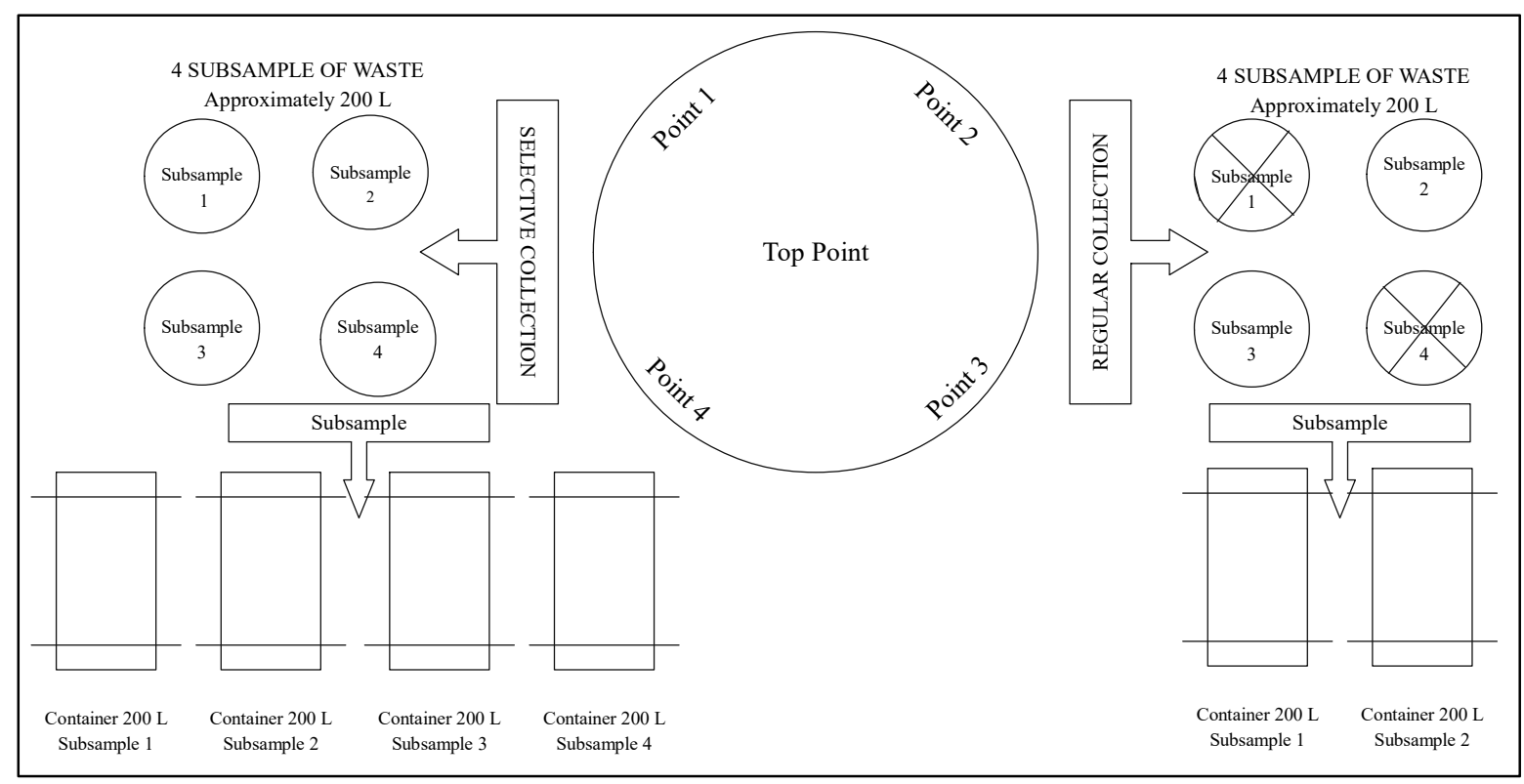

Figure 2: Sampling scheme used for the characterization of household waste. Source: Peresin et al. (2009)

Table 2: Registration form used for characterization data of the samples derived from selective collection (4 subsamples).

\begin{tabular}{|c|c|c|c|c|c|c|}
\hline \multicolumn{3}{|l|}{ Waste } & $\begin{array}{c}\text { Subsample A } \\
(\mathrm{Kg})\end{array}$ & $\begin{array}{c}\text { Subsample B } \\
(\mathrm{Kg})\end{array}$ & $\begin{array}{c}\text { Subsample C } \\
(\mathrm{Kg})\end{array}$ & $\begin{array}{c}\text { Subsample D } \\
(\mathrm{Kg})\end{array}$ \\
\hline \multicolumn{7}{|l|}{ Organic matter* } \\
\hline \multicolumn{7}{|l|}{ Wood * } \\
\hline \multicolumn{7}{|l|}{ Paper** } \\
\hline \multicolumn{7}{|l|}{ Paperboard** } \\
\hline \multirow[t]{3}{*}{ Glass ** } & \multicolumn{2}{|c|}{ Plane } & & & & \\
\hline & \multicolumn{2}{|c|}{ Colorless } & & & & \\
\hline & \multicolumn{2}{|c|}{ Color } & & & & \\
\hline \multirow{3}{*}{ Metals** } & \multicolumn{2}{|c|}{ Ferrous ** } & & & & \\
\hline & \multirow{2}{*}{ Non-ferrous ** } & Aluminum & & & & \\
\hline & & Others & & & & \\
\hline \multicolumn{7}{|l|}{ Plastic ** } \\
\hline \multicolumn{7}{|c|}{ Multilayer packaging (long-life) $* *$} \\
\hline \multicolumn{7}{|l|}{ Metallised packing ** } \\
\hline \multicolumn{7}{|l|}{ Cooking oil - bottles $* *$} \\
\hline \multicolumn{7}{|l|}{ Textiles / leather $* * *$} \\
\hline \multicolumn{7}{|c|}{ Toilet paper, diapers, hygiene pads $* * *$} \\
\hline \multirow{3}{*}{$\begin{array}{l}\text { Hazardous (Class I - risk } \\
\text { potential) }\end{array}$} & \multirow{3}{*}{$\begin{array}{l}\text { Chemical } \\
* * *\end{array}$} & Paints & & & & \\
\hline & & Drugs & & & & \\
\hline & & Domisanitary & & & & \\
\hline
\end{tabular}




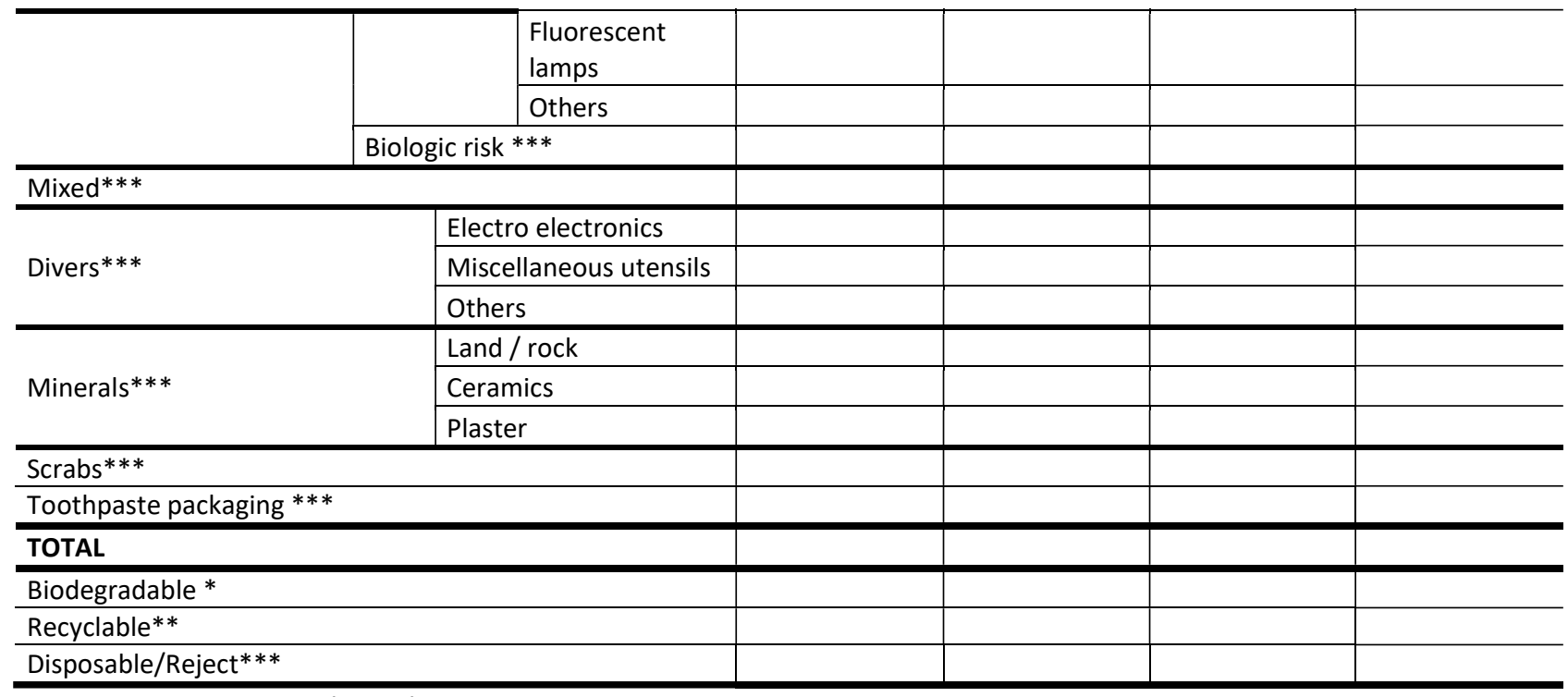

Source: Peresin et al. (2009)

After being segregated, materials were grouped according to the treatability criteria defined by Schneider and Lima (1994) in:

(i) biodegradables: materials that can be reincorporated to the biogeochemical cycles, per share of decomposing organisms;

(ii) recyclable: materials that can be reincorporated to industrial production cycles;

(iii) disposable or rejects: relating to the materials for which there are no processes that make possible the return of their constituents to natural or artificial cycles in a short time, or even that recycling is not economically viable.

According to Law no 12,305 (Brasil 2010), rejects are the materials that "after having exhausted all the possibilities for treatment and recovery for available and economically viable technological processes, do not have other possibility than the final disposal environmentally appropriate". According to this same law, only rejects should be sent to final disposal in landfills; organic waste should be referred to other treatments, such as composting or biodigesters. However, none of the studied municipalities has this condition in their solid waste management system. Currently, the municipalities send both organic waste and rejects to landfills.

The proportion of each material inside the total mass of waste generated by studied municipalities was quantified from the percentage of the materials present in the sample, extrapolated to the total generated waste that goes to each collection (mass of waste sent to landfill and to triage plants).

\section{RESULTS AND DISCUSSION}

Table 3 present in a systematic way the generation data, in mass and per capita, for regular and selective collections in the municipalities 1 and 2 . The values of generation are shown in tonnes per month (t.month $\left.{ }^{-1}\right)$, and the daily per capita generation in kg per inhabitant per day (kg/inhab.day). 
Table 3: Mass generation data and per capita waste for the regular and selective collections in the evaluated municipalities.

\begin{tabular}{l|l|c|c}
\hline \multicolumn{2}{l|}{} & Municipality 1 (2011)* & Municipality 2 (2014)** $^{*}$ \\
\hline \multirow{2}{*}{ Regular collection } & Generation (t.moth ${ }^{-1}$ ) & 400 & 928 \\
\cline { 2 - 4 } & Per capita (kg/inhab.day) & 0.545 & 0.486 \\
\hline \multirow{2}{*}{ Selective collection } & Generation (t.moth ${ }^{-1}$ ) & 12 & 289 \\
\cline { 2 - 4 } & Per capita (kg/inhab.day) & 0.016 & 0.151 \\
\hline Total generation (t.moth & (1) & 412 & 1,217 \\
\hline Total per capita (kg/inhab.day) & 0.561 & 0.637 \\
\hline
\end{tabular}

Source: * Landfill in the third municipality and triage plants.

** Landfill municipal and triage center.

Based on Table 3, it is observed that the total solid waste generation in the municipality 1 corresponds to 412 t.month $^{-1}$, while in the municipality 2 it corresponds to 1,217 t.month $^{-1}$, approximately $65 \%$ higher than municipality 1 . Noteworthy are the values of total per capita generation, which in municipality 1 is $0.561 \mathrm{~kg} /$ inhab.day and in municipality 2 is $0.637 \mathrm{~kg} /$ inhab.day, only $10 \%$ higher than municipality 1.

For regular collection, the municipality 1 has a generation of 400 t.month $^{-1}$, while the municipality 2 has a generation of 928 t.month-1, approximately $45 \%$ higher than municipality 1 . The per capita generations are, respectively, $0.545 \mathrm{~kg} /$ inhab.day to municipality 1 and $0.486 \mathrm{~kg} /$ inhab.day to municipality 2 . In this case, the per capita generation from municipality 1 is, in average, 10\% higher than municipality 2.

Regarding to the selective collection to municipality 1 , the generation is 12 t.month $^{-1}$, which represents only $2.91 \%$ of the total generation. In the municipality 2 , the generation is 289 t.month-1, representing $23.74 \%$ of the total amount generated. While the per capita generation in the municipality 1 is $0.016 \mathrm{~kg} / \mathrm{hab}$. day, in the municipality 2 it is about $0.151 \mathrm{~kg} /$ inhab.day, aproximatelly $90 \%$ higher than municipality 1.

Based on the obtained data, it is possible to observe that municipality 1 shows an overall per capita generation of $0.561 \mathrm{~kg} / \mathrm{inhab}$.day, while municipality 2 has a per capita generation of $0.637 \mathrm{~kg} / \mathrm{inh}$ hab.day. These values are lower than the per capita national averages exhibited by Campos (2012): $0.810 \mathrm{~kg} / \mathrm{inhab}$.day for municipalities with more than 30,000 inhabitants, and $0.770 \mathrm{~kg} /$ inhab.day for municipalities with population range between 30,000 and 100,000. Despite displaying different sizes, the evaluated municipalities have similar socioeconomic characteristics and waste collection systems, which may explain the similar per capita rates (only $10 \%$ of difference).

In Brazil, in percentage terms, the per capita generation of solid waste has grown more than the population, and GDP has grown less than the generation of solid waste. In 2009, there was a reduction in GDP growth, while the total waste generation continued to increase. On the other hand, in Western European countries efforts have been made to reduce, or at least stabilize, the per capita generation of solid waste since 2000. Directives were published on policies for generation and consumption. However, the goals are far from being achieved, according to the $5^{\text {th }}$ Environment Action Program (EAP), adopted in 1992 by the European Parliament. One purpose of this program was reduce the per capita generation of municipal solid waste and stabilize it, by the year 2000, at the average values 1985 (Campos 2012). 
The characterization results are presented below, separately for regular and selective collection respectively.

\section{Regular Collection}

Figure 3 shows the solid waste composition from regular collection according to the treatability criteria earlier described (biodegradable, recyclable and disposable), evaluated by neighbourhood, as well as the average of neighbourhoods for municipalities 1 and 2.

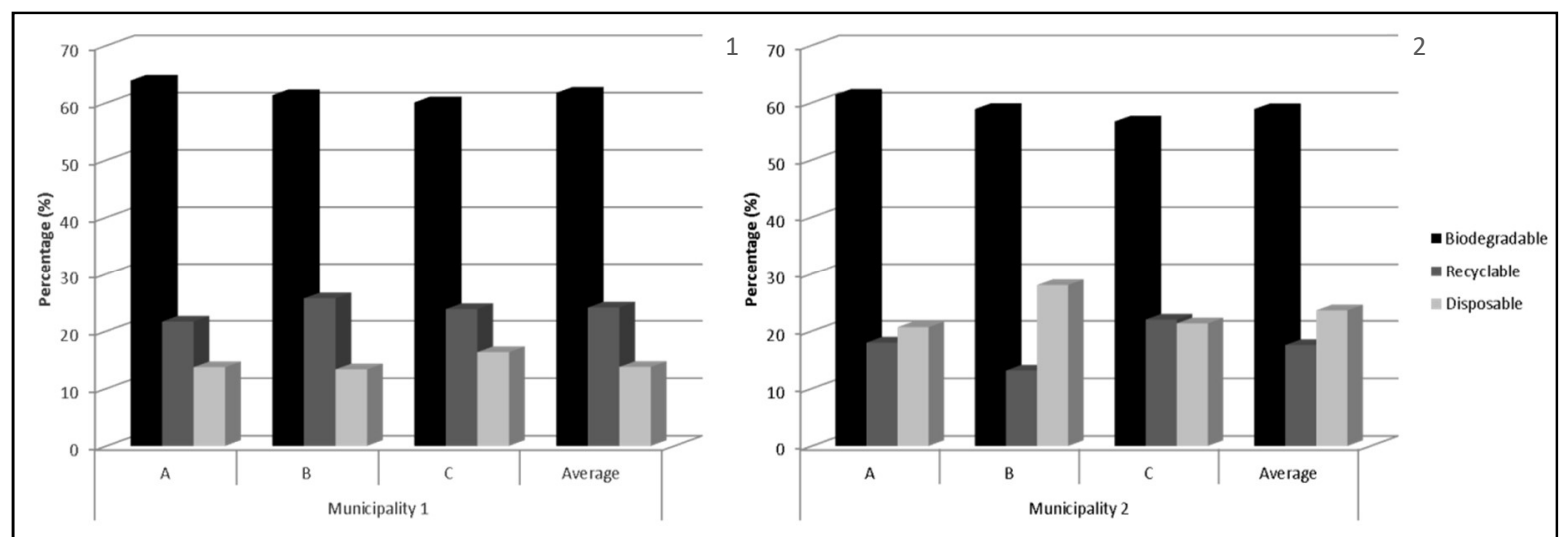

Figure 3: Waste composition sent to regular collection of municipalities 1 and 2. Source: ${ }^{1}$ Peresin and Schneider (2013)

${ }^{2}$ Unpublished data

Based the data presented on Figure 3, it can be observed that municipality 1 generates approximately $62 \%$ of biodegradable, $24 \%$ recycled and $14 \%$ of disposable materials. The best segregation rate was verified in the high-class neighbourhood, which allocated the lowest amount of recyclables (22.4\%) to regular collection. In municipality 2 , the average of biodegradable, recyclable and disposable materials are, respectively, $61 \%, 17 \%$ and $22 \%$. The best segregation rate was observed in middle-class neighbourhood, where it was identified the lower amount of recyclable in the regular collection (12.11\%).

In Nablus district (Al-Khatib et al., 2010), the main components on the weight basis of the regular collection are composed by organics (garden and food waste; 65.1\%), paper and card (9.1\%) and plastic (7.6\%). The percentage of biodegradable and plastic materials is similar to the results obtained in this study. In Figure 4, it possible to check the average percentage of the types of waste for regular collection in the municipalities evaluated.

Among $24 \%$ of recyclable materials that are found in the regular collection of municipality 1 , it was observed the preponderant presence of plastic $\left(8.8 \%-35.2\right.$ t.month $\left.{ }^{-1}\right)$, paper $\left(6.4 \%-25.6\right.$ t.month $\left.^{-1}\right)$ and cardboard $\left(3.1 \%-12.4\right.$ t.month $\left.^{-1}\right)$. In municipality 2 , on the other hand, the most representative materials found among $19,5 \%$ of recyclable materials disposed in the regular collection were plastic $(8.8 \%-81.7$ t.month $\left.{ }^{-1}\right)$; multilayer packaging $\left(1.2 \%-11.1\right.$ t.month $\left.^{-1}\right)$; paper $\left(2.2 \%-20.4\right.$ t.month $\left.{ }^{-1}\right)$ and paperboard $(1.9 \%$ -17.6 t.month $\left.{ }^{-1}\right)$. 

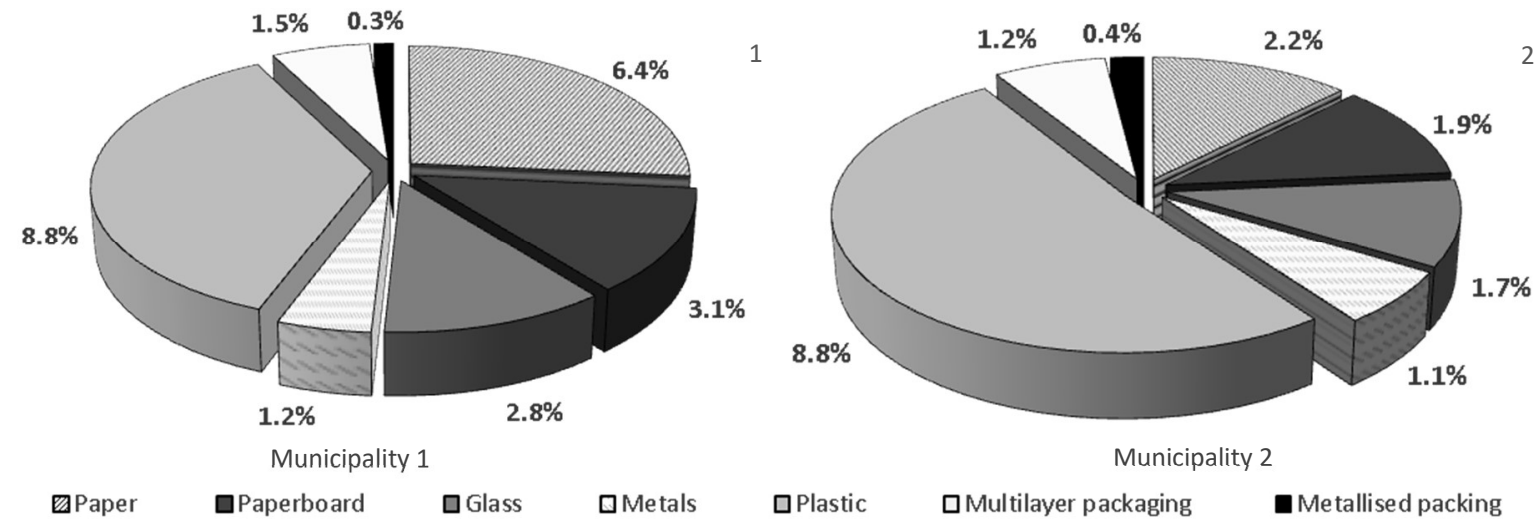

Figure 4: Average percentage of categories / materials from waste forwarded for regular collection of municipalities 1 and 2. Source: ${ }^{1}$ Peresin and Schneider (2013)/ ${ }^{2}$ Unpublished data

Experiences cited by Azevedo (2004) demonstrate the USA's efforts to promote the reduction of organic matter in the household solid waste by encouraging practices as composting of garden pruning. In Belgium there is a regulation that imposes on municipalities a charge when the amount of collected waste is higher than permitted, besides of encourage the use of composting systems. In Italy, there is a growing expansion of selective collection, among other strategies to avoid sending out wastes to landfill.

\section{Selective Collection}

Figure 5 shows the composition of waste intended for selective collection in each municipality and in each evaluated neighbourhood, as well as the average between them, grouped by the treatability criteria (biodegradable, recyclable and disposable).
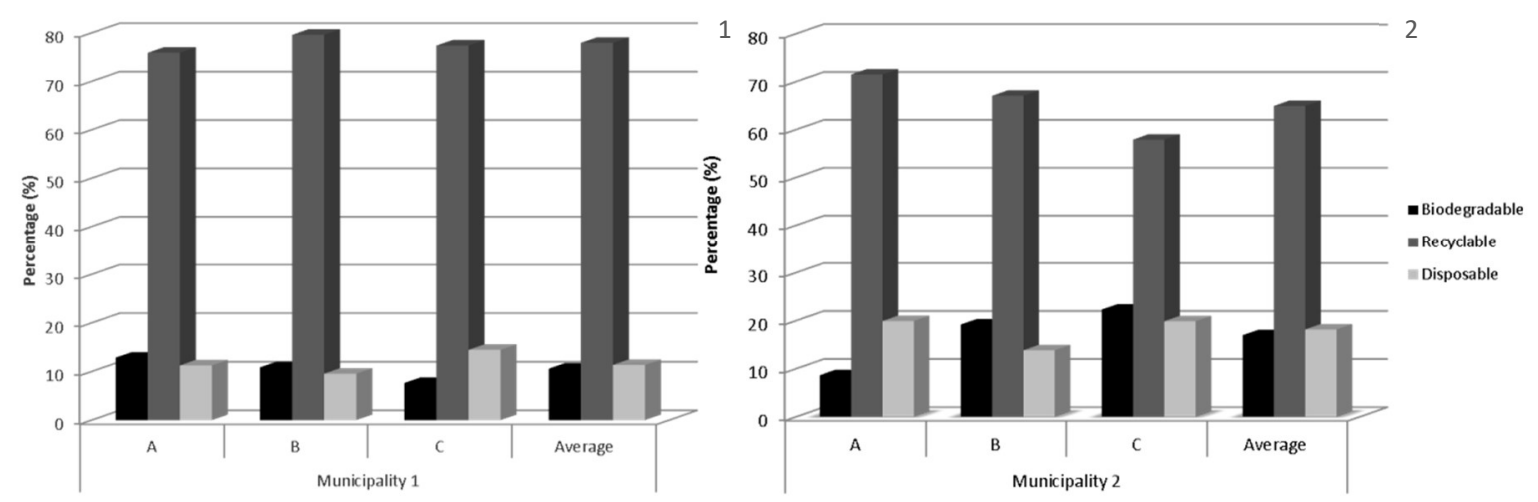

Figure 5: Waste composition sent to regular collection of municipalities 1 and 2. Source: ${ }^{1}$ Peresin and Schneider (2013) / ${ }^{2}$ Unpublished data

Based the data presented on Figure 4, it can be observed that municipality 1 earmark about $77 \%$ of recyclable waste for selective collection. The best segregation rate was observed in the middle-class neighbourhood, which allocated the lowest amount of biodegradable waste (79\%) for this collection. In municipality 2 , the selective collection is composed by $65 \%$ of recyclable waste. The best segregation rate was verified in the high-class neighbourhood, where it was identified the lowest amount of biodegradable 
waste (71.2\%). Annual household income, home-ownership status, and level of education attained by the lead recycler were significantly associated with recycling efficiency (Owens et al. 2000).

The mean percentage of waste typologies destined for selective collection, especially the category of recyclable, is shown in Figure 6.

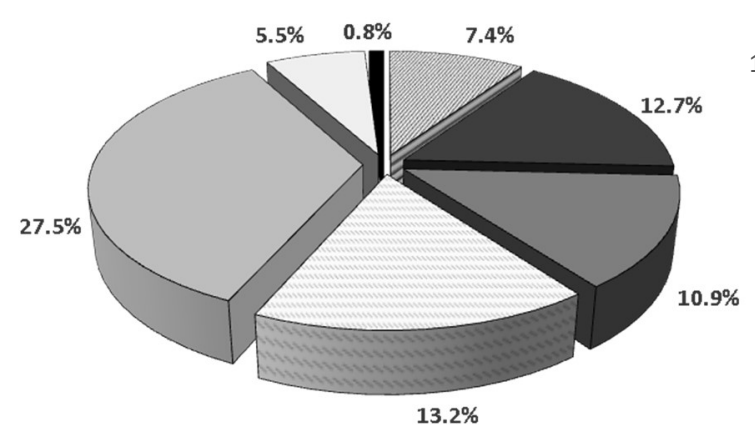

Municipality 1

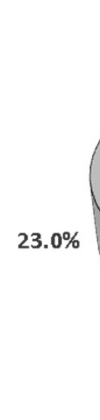

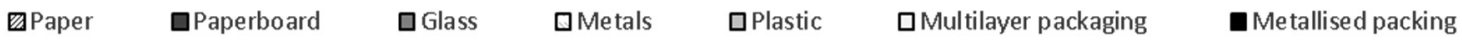

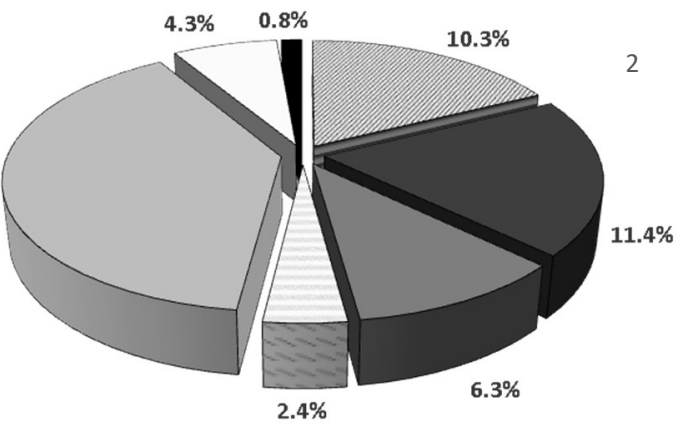

Municipality 2

Figure 6: Average percentage of categories / materials from waste forwarded for selective collection of municipalities 1 and 2. Source: ${ }^{1}$ Peresin and Schneider (2013) / ${ }^{2}$ Unpublished data

Among $77.9 \%$ of recyclable materials that are found in the selective collection of municipality 1 , it was observed the preponderant presence of plastic $\left(27.5 \%-3.3\right.$ t.month $\left.^{-1}\right)$, metal $\left(13.2 \%-1.6\right.$ t.month $\left.^{-1}\right)$ and paperboard $\left(12.7 \%-1.5\right.$ t.month $\left.^{-1}\right)$. In municipality 2 , on the other hand, the most representative materials found among $58 \%$ of recyclable materials disposed in the selective collection were plastic ( $23 \%$ 66.5 t.month $\left.{ }^{-1}\right)$; paperboard $\left(11.4 \%-32.9\right.$ t.month $\left.{ }^{-1}\right)$; and paper $\left(10.3 \%-29.8\right.$ t.month $\left.{ }^{-1}\right)$.

Regarding the amount of waste destined to selective collection in each one of the evaluated municipalities, it was observed that only $3 \%$ and $24 \%$ of total generated waste by municipality 1 and 2 is actually sent for recycling. The obtained rates for the studied municipalities are respectively upper and lower at $5 \%$ than the Malaysia's recycling rate, that was verified by Aja et al. (2014). It can be seen that the percentage of each waste typology destined for regular collection, the population's segregation in the different social classes and the per capita rate are similar among municipalities.

Comparing the studied municipalities regarding to selective collection, the municipality 1 has a per capita generation of $0.016 \mathrm{~kg} /$ inhab.day, while the municipality 2 the per capita generation rate is 0.134 $\mathrm{kg} /$ inhab.day. Municipality 1 showed a better waste segregation that is sent for selective collection, with $77.2 \%$ of recyclable materials, while municipality 2 has $58 \%$ of recyclable materials. This result may be related to the fact that in municipality 1 , the solid waste collectors conduct a package pre-selection during the collection, discarding those that are too heavy, since it configures the presence of organic matter The action's plus point is that a fewer amount of non-recyclable waste is sent to triage plants, however it does reduce the coverage of selective collection and increases the amount of recyclables referred for to landfill.

The middle-class neighbourhood in municipality 1 showed the best separation rate for selective collection, while the population of the high-class neighbourhood has had the worst segregation. In 
municipality 2 , the most efficient segregation was observed in the high-class neighbourhoods, while the worst segregation was observed in the lower-class neighbourhood.

It should be highlighted that there are still loads of biodegradable and disposable waste for selective collection, in both municipalities, which makes it difficult segregation in screening plants, generating odors and nuisance to workers at these sites. Furthermore, the mixture of materials at generating source contributes to the loss of quality of recyclable material, in particular as regards at paper and cardboard waste, which absorb moisture. These factors also end up interfering directly in increased costs with the removal and transport of waste for final disposal in landfill.

\section{CONCLUSIONS}

The management of household waste in the evaluated municipalities is performed by outsourced companies that respond by phases of collection and final disposal. The larger municipality showed better efficiency and coverage of selective collection. It was observed that the per capita waste in both municipalities are closer, despite of differences in populations sizes and social and economic characteristics. The values of per capita rates in municipalities are lower than the national indices presented in the National Sanitation Information System.

Also, based on studies carried out, it was observed the presence of the biodegradable materials in selective collection (average 14\%), and the recyclable materials in regular collection (average 21\%). It indicates the need for continued work of environmental education and awareness, in both municipalities, for the advancement of these indices.

The neighbourhoods that have better segregation, in both collections, and in both municipalities, were the neighbourhoods of high and middle-classes. In these neighbourhoods, theoretically, the population has greater access to education and information. The neighbourhoods with the lowest quality in waste segregation were the lower-class neighbourhoods, confirming the indicative of less accessibility to knowledge referent to proper waste segregation.

Finally, it is emphasized that a population's efficient segregation corroborates with activities in the triage plants, as well as for increasing the potential recovery of waste recyclable and increase the useful life of landfills. Proper segregation of solid waste affords a glimpse at future implementations of technology alternatives for the treatment and disposal of waste. Would also facilitate the research for alternatives to meet the goal defined by the National Solid Waste Policy for allocation composting or digestion of organic waste, recycling of recyclable materials and disposal in landfills only disposable waste/rejects. 


\section{ACKNOWLEDGMENTS}

The authors thank both municipalities for funding the research; Civil Engineer student Geise Macedo dos Santos - BIC/UCS scholarship - for producing the localization map; and all professionals for assisting the fieldwork.

\section{REFERENCES}

ABRAMOVAY, R.; ESPERANZA J. S.; PETITGAND, C.. Lixo zero: gestão de resíduos sólidos para uma sociedade mais próspera. São Paulo: Planeta Sustentável: Instituto Ethos, 2013.

AJA, O. C.; OSEGHALE, S. D.; AL-KAYIEM, H. H.. Review and Evaluation of Municipal Solid Waste Management - Practices in Malaysia. The Journal of Solid Waste Technology and Management, v.40, n.3, p.215-232, 2004.

AL-KHATIB, I. A., MONOU, M., ZAHRA, A. S. F. A., SHAHEEN, H. Q., KASSINOS, D.. Solid waste characterization, quantification and management practices in developing countries. A case study: Nablus district - Palestine. Journal of Environmental Management, v.91, p.1131-1138, 2010.

AZEVEDO, G. O. D.. Por menos lixo: a minimização dos resíduos sólidos urbanos na cidade do Salvador/Bahia. Dissertação (Mestrado em Engenharia Ambiental Urbana) Universidade Federal da Bahia, Salvador, 2004.

BESEN, G. R.; RIBEIRO, H.; GUNTHER, W. M. R.; JACOBI, P. R. Selective waste collection in the São Paulo Metropolitan Region: impacts of the National Solid Waste Policy. Estudos avançados, v.17, n.3, p.259-278, 2014.

BRASIL. Lei no 11.445, 05 de janeiro de 2007. Diretrizes nacionais para o Saneamento Básico. 2007.

Brasil. Lei no 12.305, de 02 de agosto de 2010. Política Nacional de Resíduos Sólidos. 2010.

CAMPOS, H. K. T.. Renda e evolução da geração per capita de resíduos sólidos no Brasil. Revista Engenharia Sanitária e Ambiental, v.17, n.2, p.171-180, 2012.

EDJABOU, M. E., JENSEN, M. B., GÖTZE, R., PIVNENKO, K., PETERSEN, C., SCHEUTZ, C., ASTRUP, T. F.. Municipal solid waste composition: Sampling methodology, statistical analyses, and case study evaluation. Waste Management, v.36, p.12-23, 2015.

GALLARDO, M. C., PERIS, M., COLOMER, F. J.. Methodology to design a municipal solid waste generation and composition map: A case study. Waste Management, v.34, p.1920-1931, 2014.

IBGE. Instituto Brasileiro de Geografia e Estatística. Cidades@. 2015.

JACOBI, P. R.; BESEN, G. R.. Gestão de resíduos sólidos em São Paulo: desafios da sustentabilidade. Estudos avançados, v.25, n.71, p.135-158, 2011

MINGHUA, Z., XIUMIN, F., ROVETTA, A., QICHANG, H., VICENTINI, F., BINGKAI, L., GIUSTI, A., YI, L.. Municipal solid waste management in Pudong New Area, China. Waste Management, v.29, p. 1227-1233, 2009.

OWENS, J., DICKERSON, S., MACINTOSH, D. L.. Demographic covariates of residential recycling efficiency. Environment And Behavior, v.32, n.5, p.637-650, 2000.

PERESIN, D., SCHNEIDER, V.E., TEIXEIRA, C.E., POLETTO, M., FINKLER, R., MOTTA, E.M.T.. Composição física e gravimétrica de resíduos sólidos domésticos - uma análise dos métodos utilizados no Brasil. In: SEMINÁRIO REGIONAL SUL DE RESÍDUOS SÓLIDOS, 3. Anais. Caxias do Sul, 2009.

PERESIN, D.; SCHNEIDER, V. E.. Avaliação econômica da gestão dos resíduos sólidos urbanos em um município de pequeno porte. In: CONGRESSO BRASILEIRO DE ENGENHARIA SANITÁRIA E AMBIENTAL, 27. Anais. Goiânia, 2013.

SCHNEIDER, V.E.; LIMA, L. M. Q.. Characterization of domestic solid waste for defining management models Case Study: Bento Gonçalves, Brazil. In: CONGRESO INTERNACIONAL DE QUIMICA DE LA ANQUE, 3. Anais. Puerto de la Cruz, 1994.

SEO, S., ARAMAKI, T., HWANG, Y., HANAKI, K.. Environmental impact of solid waste treatment methods in Korea. Journal of Environmental Engineering Div., v.130, n.1, p.81-89, 2004.

SNIS. Sistema Nacional de Informações sobre Saneamento. Diagnóstico do Manejo de Resíduos Sólidos Urbanos 2010. 2014. 